\title{
LA LECTURA ESPIRITUAL DE LA ESCRITURA EN LOS PADRES DE LA IGLESIA: UNA INTRODUCCIÓN
}

\author{
Spiritual Reading of the Scriptures by the Church Fathers: An Introduction
}

\section{Ana Cristina Villa Betancourt ${ }^{1}$}

\section{Resumen}

El artículo presenta, brevemente y desde diferentes ángulos, los principales rasgos de la lectura e interpretación espiritual de la Sagrada Escritura practicada por los Padres de la Iglesia, para dar a conocer sus características y presupuestos. Las secciones de este exploran en qué consiste la lectura espiritual de la Escritura y la ejemplifican con algunos textos patrísticos. Se concluye que, en muchos aspectos, hay gran sintonía entre ellos y las búsquedas de la teología contemporánea, en especial, en la metodología empleada para la exégesis bíblica; en efecto, hoy como entonces, se busca regresar a la integralidad del saber y proponer un renovado sentido del misterio para el hombre contemporáneo.

Palabras clave: Exégesis espiritual; Hermenéutica bíblica; Cristocentrismo; Henri de Lubac; Padres de la Iglesia; Sagrada Escritura.

\section{Abstract}

The article introduces briefly and from different perspectives the main features of the spiritual reading and interpretation of the Holy Scriptures developed by the Church Fathers, presenting both their characteristics and presuppositions. Thus, it explores what is understood by spiritual reading of the Scriptures and introduces some examples of patristic writings. It concludes that in some respects there is correspondence between these

1 Doctora en Teología Patrística por la Pontificia Universidad Gregoriana. Docente de la Universidad Pontificia Bolivariana. Correo electrónico: ana.villab@upb.edu.co. 
writings and the inquiries of contemporary theology, especially in the methods used for biblical exegesis. Indeed, then, as now, it was pretended to return to a comprehensive knowledge and to develop a reinvigorated meaning of the mystery for contemporary human beings.

Keywords: Spiritual Exegesis; Biblical Hermeneutics; Christ-centrism; Henri de Lubac; Church Fathers; Holy Scriptures.

\section{Introducción}

El objetivo de este escrito ${ }^{2}$ es introducir los principales rasgos de la lectura e interpretación espiritual de la Sagrada Escritura practicada por los Padres de la Iglesia ${ }^{3}$ y proponer algunas iluminaciones que este método puede ofrecer a la práctica de la teología hoy.

La lectura y el comentario de las Escrituras fue la base desde la cual los Padres desarrollaron su ciencia teológica; para su hermenéutica, practicaban lo que proponemos denominar genéricamente "exégesis espiritual" o "lectura espiritual" de la Escritura. Aunque hay diferencias de autor a autor, y los modos de interpretación van cambiando con las épocas y presentan diferencias entre las escuelas teológicas, ${ }^{4}$ en virtud del trabajo introductorio que se presenta, el interés se centra en los rasgos comunes de esta "lectura espiritual" para intentar caracterizarlos.

Este artículo se inspira en los planteamientos de De Lubac (1971, pp. 405-482; 1988, pp. 117-151), para sistematizarlos y complementarlos con los de autores más recientes. De Lubac fue un gran estudioso de la exégesis antigua, patrística y medieval, quien, a partir de su estudio, ofreció importantes contribuciones a la teología de su tiempo. Afirmaba que la riqueza de la comprensión de la Escritura que encontramos en

2 Basado en el texto de una conferencia ofrecida en la Semana de Formación para la Vida Consagrada, organizada por la Arquidiócesis de Medellín, Delegación para la Vida Consagrada y la Universidad Pontificia Bolivariana, 20 y 21 de agosto de 2020.

3 En este artículo, usaremos la expresión Padres de la Iglesia para nombrar a los "autores de los primeros siglos cristianos invocados universalmente como testigos directos o indirectos de la doctrina cristiana o de la vida de la Iglesia en una época determinada", según expresión de André Mandouze en el III Congreso Internacional de Estudios Patrísticos de Oxford en 1959. Los cuatro criterios clásicos elaborados por Vicente de Lerins (ca. 380-ca. 450) que daban el nombre de Padres a los autores que tuvieran santidad de vida, ortodoxia de doctrina, aceptación por parte de la comunidad y antigüedad, suelen hoy considerarse superados y han sido reemplazados por esta categoría más general que llama Padres a los exegetas de la antigüedad, testigos privilegiados del modo como la Iglesia antigua comprendía e interpretaba la Escritura, lo cual los hace testigos privilegiados de la Tradición (Padovese, 1996, pp. 18-21).

4 En la patrística suelen distinguirse dos grandes escuelas teológicas: la de Alejandría y la de Antioquía; respecto de la exégesis, las diferencias entre ambas escuelas son notables. La exégesis alejandrina suele apoyarse más en la alegoría y la tipología mientras que la antioquena practicaba una exégesis que privilegiaba la interpretación literal e histórica. Sin embargo, los rasgos de la lectura espiritual que aquí se proponen pueden aplicarse en sentido amplio a la exégesis practicada por padres que pueden clasificarse como pertenecientes a cualquiera de las dos escuelas. 
los Padres se apoya en una cierta "connaturalidad espiritual" con ella. Los Padres están convencidos de que quien lee e interpreta la Escritura debe estar inspirado por el mismo Espíritu Santo que asistió al hagiógrafo; el Espíritu que inspiró la composición de la Escritura es el mismo que nos ayuda a comprenderla, tanto ayer como hoy. Esta convicción constituye la raíz patrística de la importante frase de Dei Verbum que invita a leer e interpretar la Escritura "con el mismo Espíritu con que se escribió" (Dei Verbum, 1965, n. ${ }^{\circ}$ 12). Los Padres no tenían los métodos críticos y científicos que poseemos hoy para la exégesis, pero tenían, en cambio, esta connaturalidad que se constituía en su modo propio de leer la Escritura. La nuestra es una época más científica y racional y hasta racionalista, mientras que la de los Padres, la antigüedad cristiana, era más contemplativa, no se separaba la teología que hoy llamamos dogmática de la espiritual, ni de la exégesis bíblica. Todo era "ciencia de Dios", sabiduría de Dios.

La finalidad de aproximarnos al modo patrístico de leer la Escritura no es para aplicarlo sin más hoy, imitándolo externamente, pues no podemos trasponer de manera simplista su manera de leer la Escritura a nuestro tiempo. Decía el mismo De Lubac (1971): "Ellos son testigos de una primavera, de una adolescencia y esto es privilegio de ellos. En compensación, por nuestra parte, a nosotros nos toca ser la edad de la madurez" (p. 470). Lo que se intenta proponer a continuación es dar a conocer y comprender el valor de esta lectura espiritual de la Escritura como ayuda para algunas de los problemas y desafíos que encuentra la teología hoy.

En este sentido, para introducirnos a la experiencia de la Escritura que tenían los Padres desarrollamos cuatro puntos: la búsqueda del Misterio de Dios en las Escrituras, las características de la "lectura espiritual" de la Escritura, que se basa en una analogía entre Escritura y Encarnación, pues Cristo es el principio clave para su interpretación. Se concluye proponiendo brevemente algunas luces para el quehacer teológico hoy.

\section{Buscar en las Escrituras el acceso al Misterio}

San Jerónimo decía: "Cuando oras, hablas a tu Esposo; cuando lees, Él te habla a ti" (Epístola 22,25), ${ }^{5}$ y esta frase puede servir como punto de partida para ilustrar el método del que venimos hablando. En efecto, los Padres tenían una relación especial, única, con la Escritura: sabían leerla escudrińando con paciencia su misterio. Quizá porque sentían todavía los ecos de la predicación de los apóstoles, quizá porque la leían en el seno de sus comunidades vivas de fe; en todo caso, la consideraban palabra viva de Dios, fuente incesante de agua que calmaba la sed de sus corazones.

Gregorio de Nisa, por ejemplo, nos invita en sus propias palabras a "escudriñar las Escrituras" con esmero, esfuerzo y adiestramiento análogos a los de los atletas que se esfuerzan por competir dignamente:

Ciertamente uno, por más que exagerara, no podría expresar dignamente con la palabra, cuántas fatigas supone recorrer este texto; ${ }^{6}$ quienes compiten y se adiestran para alcanzar pensamientos firmes, se han de empeñar a fin de que el discurso no sea erróneo, sino que se preserve una inteligencia recta y verdadera en

5 "Oras loqueris ad sponsum; legis, ille tibi loquitur".

6 Se refiere al libro del Eclesiastés. 
toda la complejidad del pensamiento. Sin embargo, ya que también esto es precepto del Señor: escudriñar las Escrituras, es totalmente necesario - aunque nuestra inteligencia, siguiendo la verdad, no alcance la grandeza de los pensamientos- que de ningún modo ella descuide el mandamiento del Señor y que se empeñe en el discurso con todas sus fuerzas. Escudriñemos, por tanto, el texto propuesto cuanto podamos. Pues seguramente quien ha dado el mandamiento de escudriñar dará también la fuerza para esto, como está escrito: El Señor dará la palabra con mucho poder a los que evangelizan (Sal 67, 2). (Homilías sobre el Eclesiastés 1,1)

Según estas palabras, el cristiano debe poner su máximo empeño recordando que no queda abandonado a sus fuerzas para escudriñar el texto, sino que cuenta también con la fuerza y el poder del Señor.

San Agustín, por su parte, comenta:

Los que leen inconsideradamente se engañan en muchos y polifacéticos pasajes obscuros y ambiguos, sintiendo una cosa por otra, y en algunos lugares no encuentran una interpretación, aun sospechando que sea ella incierta; así es de oscura la espesa niebla con que están rodeados ciertos pasajes. No dudo que todo esto ha sido dispuesto por la Providencia divina para quebrantar la soberbia con el trabajo, y para apartar el desdén del entendimiento, el cual no pocas veces estima en muy poco las cosas que entiende con facilidad. (La doctrina cristiana II,6,7)

Ciertos pasajes de la Escritura están rodeados de una "espesa niebla" (densissima caligo) y en ello puede verse una disposición de la Providencia para invitar a la humildad y a empeńarse en una búsqueda activa que permita desentrańar los signos para conocer cuanto Dios ha querido en ellos comunicar a los hombres.

Los Padres, como nosotros, experimentaban a veces cierto desconcierto al leer la Escritura, en especial, algunos pasajes del Antiguo Testamento. ¿Cómo acercarse a estos textos? ¿Qué debemos ir a buscar en ellos? Podemos reconocer la riqueza de los textos del Antiguo Testamento que nos informan sobre el pasado, que nos ayudan a conocer la religión de Israel; podemos encontrar belleza en sus oraciones, reconocer el valor universal de muchas de sus normas... Pero los Padres van a estos textos en busca de algo más; lo mencionado no es suficiente para ellos: buscan en la Escritura al Dios que se revela. En palabras de Orígenes:

Ya que si alguien, por ejemplo, aduce el caso de las hijas de Lot, que parecen, contrariamente a la ley de Dios, haber copulado con su padre; o las dos mujeres de Abrahán, o las dos hermanas que estuvieron casadas con Jacob, o de las dos criadas quien aumentaron el número de sus hijos, ¿qué otra respuesta podría ofrecérsele, sino que estos eran ciertos misterios y formas de cosas espirituales, pero que somos ignorantes de qué naturaleza son?

Incluso cuando leemos sobre la construcción del tabernáculo, consideramos cierto que las descripciones escritas son figuras de ciertas cosas ocultas; pero adaptar estas a sus normas apropiadas, y abrir y discutir cada punto individual, pienso que es sumamente difícil, por no decir imposible. Que esta descripción, sin embargo, esté llena de misterios no escapa ni al entendimiento común. Pero toda la parte de narrativa, relacionando con los matrimonios, o con el engendramiento de hijos, o las batallas de clases diferentes, o cualquier otra historia, ¿qué otra cosa además se puede suponer salvo formas y figuras de cosas ocultas 
y sagradas?... si se buscara el conocimiento divino, como debería ser, en espíritu religioso y santo, y con la esperanza de que muchos puntos serán abiertos por la revelación de Dios — ya que al sentido humano ellos son sumamente difíciles y oscuros- entonces, quizás, quien busca de tal manera encontrará lo que es permitido descubrir. (Tratado de los principios, lib. IV, cap. 2, n. ${ }^{\circ} 2$ )

Como el anterior ejemplo permite ilustrar, los Padres pudieron, mediante su interpretación espiritual, apropiar los textos del Antiguo Testamento a su experiencia cristiana, asumiéndolos como Escritura Sagrada que completaba la Revelación cristiana, porque la preanunciaba y permitía comprenderla con mayor profundidad. ${ }^{7}$ Al buscar el sentido espiritual, pudieron abrir toda la Escritura a la comprensión cristiana y hacerla vigente según el nuevo horizonte de su fe (Kannengiesser, 2004, p. 13).

Notemos que esta interpretación puede llamarse "espiritual" en un sentido "fuerte". Es decir, no es espiritual en cuanto meditación edificante de la Sagrada Escritura, sino que se refiere a espiritual en cuanto que busca acceder a la intención más profunda de la Revelación en la palabra de las Escrituras. Es una lectura que intenta ir más allá del estudio de la Palabra con categorías puramente humanas, busca sondear la profundidad que se esconde bajo la superficie, intenta descubrir el centro misterioso en torno al cual todo rota, acceder al Misterio cristiano al que todo apunta. Orígenes, uno de los autores que más teorizó sobre esta lectura espiritual y más abundantemente la practicó, explica la necesidad de buscar tras las palabras, intentando acceder a los misterios y las "cosas divinas".

Entonces, finalmente, que las Escrituras han sido escritas por el Espíritu de Dios, y tienen un significado, no solo el que es evidente a primera vista, sino también otro, que se escapa del conocimiento de la mayoría. Porque aquellas [palabras] que están escritas son las formas de ciertos misterios y las imágenes de las cosas divinas. Respecto a lo cual hay una opinión universal en toda la Iglesia, que la ley entera es verdaderamente espiritual; pero que el significado espiritual que la ley encierra no es conocido a todos, sino únicamente a aquellos a quienes es concedida la gracia del Espíritu Santo en la palabra de sabiduría y de conocimiento. (Tratado de los principios, I, pref., n. ${ }^{\circ} 8$ )

Para los Padres, la verdadera comprensión de la Escritura no se agotaba en comprender los hechos o las palabras, sino que se daba cuando la Palabra alcanzaba su fin y sentido último: hacer encontrar al hombre con Dios (Fiedrowicz, 2010, p. 105). En su interpretación de la Escritura, los pastores "partían el pan de la palabra" para los fieles, junto con el pan eucarístico, para ayudarlos a acceder a los misterios revelados por Dios en el texto sagrado antes de participar en la comunión con el cuerpo y la sangre de Cristo (Dell'Osso, 2016, p. 16).

7 Kannengiesser (2004) al respecto sostiene: "If patristic exegesis is at the very core of the cultural legacy of the early church, it is because generations of believers built up the church by identifying with the divine revelation received from the Bible. These believers initiated a rare, if not unique, process in the history of religions: they took over an intrinsically exclusivist body of sacred writings, proper to a particular religious tradition, and appropriated it to their own tradition, a tradition born out of the former one, but open to a spiritual self-definition which rejected that proper and genuine exclusivism" (p. 13). 


\section{Características de una "lectura espiritual” de la Sagrada Escritura}

Pasemos a enumerar algunas características de la "lectura espiritual" de las Escrituras propia de los Padres de la Iglesia:

1. Es "espiritual" porque viene, en especial, del Espíritu Santo. Es cierto que también el sentido literal viene de Él, puesto que, en realidad, todo sentido de la Escritura es inspirado; pero el sentido literal no agota la intención del Espíritu. El sentido espiritual no es dado por el autor humano, sino que es el sentido enseñado por el Espíritu de la verdad, el Espíritu de Cristo; es el sentido que relaciona al creyente con Cristo, al que se accede en el Espíritu, y no tanto ni en primer lugar por métodos científicos (De Lubac, 1971, pp. 422-423). En palabras de Orígenes:

La razón de la aprehensión errónea de todos estos puntos de parte de quienes hemos mencionado arriba [los judíos], no es otra que esta, que la Escritura santa no es entendida por ellos según su sentido espiritual, sino según su significado literal. Por lo tanto procuraremos, en la medida en que nuestra moderada capacidad lo permitirá, indicar a los que creen que las Escrituras santas no son composiciones humanas, sino que han sido escritas por inspiración del Espíritu Santo, y que se nos han transmitido y confiado por la voluntad de Dios Padre y por su unigénito Hijo Jesucristo, lo que nos parece a nosotros, que observamos las cosas por medio de un modo correcto de entendimiento, que es el modelo y disciplina que nos han entregado los apóstoles por Jesucristo; las que ellos nos transmitieron en sucesión a su posteridad, los maestros de la Iglesia santa. (Tratado de los principios, lib. IV, cap. 2, n. $\left.{ }^{\circ} 2\right)$

2. En referencia a lo anterior, los frutos de la lectura espiritual de la Escritura no son plenamente objetivables ni reproducibles. Con el sentido espiritual, se apunta a hacer theologia (ciencia de Dios) y no technologia (de techné: arte, oficio, técnica), para entrar, con el debido respeto, al misterio insondable de Dios, percibir su voz misma en el texto (Fiedrowicz, 2010, pp. 108-109). Se trata de hacer ciencia de Dios basándose en el hecho de que, al pronunciar su Palabra, Dios ha querido hacer al ser humano su interlocutor.

3. Con la lectura espiritual, tampoco se niega la historicidad y humanidad de los acontecimientos que se narran; pero, sin detenerse en ellos, se busca la "fuerza espiritual de la historia", con la convicción de que los hechos que se narran están "cargados de eternidad" porque el Verbo se hizo carne y plantó su morada entre nosotros (De Lubac, 1988, p.119). Buscar un sentido espiritual hace parte del dinamismo propio de la Encarnación, como se verá más adelante.

4. En consecuencia, la lectura espiritual no busca establecer un sentido que corresponda a uno u otro símbolo, ni solo o, sobre todo, a un libro dado, sino que es un sentido que corresponde al "todo" de la Escritura, a su unidad misma. Lo que llamamos Antiguo y Nuevo Testamento constituye una única obra, una doble Alianza que es una única Alianza, una doble "economía", que se manifiesta en la historia, pues Dios ha querido entrar en ella y asumir su lenguaje. La historia, entonces, está cargada de Palabra de Dios, en la historia se cumple de manera real pero espiritual, el misterio de Cristo y de su Iglesia (De Lubac, 1988, pp. 120-121). 
5. La lectura espiritual expresa, además, un sentido de "plenitud", un camino que avanza progresivamente hacia un telos, una meta; hay una pedagogía progresiva en la historia de la salvación, lo histórico y lo profético llega a su cumplimiento en Cristo, en la Iglesia. Las realidades que se describen en los libros bíblicos no son pasadas, son eternas.

6. La lectura espiritual es también una lectura interior, porque el dinamismo de la Ley nueva está grabado ya no en las piedras, sino en los corazones. Este sello interior de la vida del Espíritu en los cristianos, que son muchos y muy diferentes, crea una profunda unidad entre todos, unidad que trasciende las diferencias individuales, culturales y temporales.

7. Leer espiritualmente la Escritura significa, además, participar en la unidad en la verdad, porque en la tradición cristiana los términos Espiritu y verdad aparecen a menudo juntos: "El Espíritu os llevará a la verdad" (Jn 16,13). Verdad en sentido vigoroso y sustancial, en el sentido de la realidad de Cristo en contraste con las sombras y figuras que existieron antes que Él.

8. Por último, la lectura espiritual está íntimamente relacionada con la vida espiritual, puede encontrarse solo como fruto de una vida en el Espíritu y conduce a la finalidad de la vida cristiana que es la unión con Dios. El misterio cristiano no puede ser solo un curioso objeto de ciencia, sino también una relación viva que se interioriza progresivamente. El sentido espiritual es el significado que se descubre en la Escritura cuando se vive este misterio. Por eso, la comprensión espiritual de la Escritura está íntimamente asociada a la transformación cristiana y es su aspecto más luminoso. La Escritura abre su sentido más hondo a quien se acoge al don del Espíritu y camina hacia el progreso en la caridad (De Lubac, 1971, p. 424; Dell'Osso, 2016, pp. 18-19). Pasar a una comprensión espiritual es pasar al hombre nuevo que no deja de ser renovado de claridad en claridad, o, en palabras de Agustín, es levantar los ojos a los montes en busca del auxilio del Señor:

Por tanto, hermanos míos, si queréis llegar a entender, levantad vuestros ojos a este monte, erguíos hacia el evangelista, erguíos hacia su pensamiento. Pero, porque estos montes reciben la paz y, por otra parte, no puede estar en paz quien pone su esperanza en el hombre, no elevéis vuestros ojos al monte, creyendo que vuestra esperanza debe descansar en un hombre, y decid "Levanto mis ojos a los montes de donde me vendrá el auxilio" diciendo en seguida: el auxilio me viene del Señor, que hizo el cielo y la tierra...

Porque las Escrituras son servidas mediante hombres, cuando levantamos nuestros ojos a las Escrituras, levantamos nuestros ojos a los montes de donde nos vendrá el auxilio; pero, porque eran hombres esos mismos que escribieron las Escrituras, no brillaban con luz propia, sino que la verdadera Luz era ese mismo que ilumina a todo hombre que viene a este mundo... Debes decir: Levanto mis ojos a los montes de donde me vendrá el auxilio, sin atribuir a los montes la ayuda que te viene, sino diciendo a continuación: El auxilio me viene del Señor, que hizo el cielo y la tierra. (Tratados sobre el Evangelio de Juan I,6)

En fin, sintetizando lo dicho, san Ambrosio de Milán, en su comentario al Evangelio de Lucas, ofrece un buen ejemplo de lo que caracteriza una lectura espiritual, en este caso de las parábolas de la misericordia 
del capítulo 15. En ella presenta simbolismos espirituales inspirados en el hecho de que la misericordia aparezca representada sucesivamente por un pastor, una mujer y un padre:

¿Quién es este padre, ese pastor y esa mujer? ¿Acaso no representan a Dios Padre, a Cristo y a la Iglesia? Cristo te lleva sobre sus hombros, te busca la Iglesia y te recibe el Padre. Uno porque es Pastor, no cesa de llevarte; la otra, como Madre, sin cesar te busca, y entonces el Padre vuelve a vestirte. El primero, por obra de su misericordia; la segunda, cuidándote; y el tercero, reconciliándote con Él. A cada uno de ellos le cuadra perfectamente una de esas cualidades: el Redentor viene a salvar, la Iglesia asiste y el Padre reconcilia. En todo actuar divino está presente la misma misericordia, aunque la gracia varía según nuestros méritos. El pastor llama a la oveja cansada, se encuentra la dracma que se había perdido, y el hijo, por sus propios pasos, vuelve al padre y lo hace plenamente arrepentido del error que lo acusa sin cesar... Por lo que a mí se refiere, prefiero ser hijo antes que oveja, pues aunque esta es solícitamente buscada por el pastor, el hijo recibe el homenaje de su padre. (Tratado sobre el Evangelio de Lucas 7,208)

\section{Analogía entre Escritura y Encarnación}

Hay una importante analogía entre el modo como los Padres de la Iglesia entendían la Escritura y el misterio de la Encarnación del Señor. Ellos dedicaron una buena parte de sus obras a esclarecer la fe trinitaria y la fe cristológica en los primeros siglos, ante la aparición de herejías que cuestionaban o distorsionaban algunos elementos de la fe de la Iglesia y hacían urgente una formulación clara de esta. Llevaron a cabo esta tarea, ante todo y en primer lugar, siendo intérpretes de la Escritura, pues buscaron leerla "dentro" de la unidad de la fe eclesial.

Con el paso de los años, la Iglesia fue clarificando su formulación del misterio de la persona divina de Cristo: Él es verdadero Dios y verdadero hombre, manteniéndose distintas la divinidad de la humanidad en la unidad de la persona divina de Jesucristo. De manera análoga, la Sagrada Escritura es palabra humana que está cargada y permeada de la Palabra de Dios. El cuerpo de la Escritura, su letra, sus palabras, repiten la Encarnación del Verbo de Dios: análogamente a como la Palabra divina invisible asumió con la Encarnación una forma humana visible, así las realidades espirituales se hacen visibles y tangibles cuando se hacen Escritura santa. En palabras de Orígenes:

En los últimos días, el Verbo de Dios, revestido de carne por medio de María, salió a este mundo, y lo que se veía en él era diferente de lo que se entendía, pues la visión de la carne en él se manifestaba a todos, pero el reconocimiento de la divinidad se concedía a unos pocos elegidos; del mismo modo, cuando la Palabra de Dios habla a la humanidad por medio de los profetas o del legislador, no habla sin un ropaje apropiado. Y así igualmente a como allí está cubierto por el velo de la carne, aquí lo está por el velo de la letra, de modo que uno percibe la letra como la carne, pero percibe oculto en ella el sentido espiritual como allí la divinidad. (Homilías sobre el Levítico, I,1; traducción mía)

En la Encarnación, Dios se adaptó a la condición humana, abajándose por su condescendencia hasta

nosotros para elevarnos a Sí; esta condescendencia es definida así por Juan Crisóstomo: “¿Qué es esta condescendencia? Es Dios apareciendo y mostrándose no como es, sino como puede ser visto por aquellos 
que son capaces de verlo, proporcionando el aspecto que presenta de sí mismo a la debilidad de los que lo miran" (Sobre la incomprensibilidad de Dios, III,163-166; traducción mía).

De modo análogo, hay una adaptación en la Palabra de Dios contenida en la Escritura que se abaja hasta nosotros haciéndose palabra humana para elevarnos a Dios. Afirma Agustín:

En cuanto al estilo de expresión con que la Sagrada Escritura está compuesta, ¡cuán asequible es a todos, aunque a pocos es dado penetrar en ella! Como un amigo familiar, expresa sin rodeos al corazón de doctos e indoctos las verdades manifiestas que contiene. Pero aun esos misterios que oculta no los enreda con lenguaje orgulloso, a donde no se atreva a acercarse el entendimiento algo torpe o falto de preparación, como un pobre que se acerca a un rico. Por el contrario, invita a todos con humilde palabra, no solo para nutrirlos con verdades manifiestas, sino también para ejercitarlos con verdades ocultas. Lo mismo nos dice en las expresiones claras que en las obscuras. Mas para que las verdades claras no engendren fastidio, las encubre, y así excita nuestro deseo. Así con el deseo se renuevan en cierto modo, y por la renovación nos resultan más íntimas y suaves. Por este medio, los ingenios malos se corrigen, los modestos se nutren, los grandes se deleitan y todo se hace saludablemente. Solo es enemiga de esta doctrina aquella alma que por error ignora que esta es la doctrina salvadora o por enfermedad odia la medicina. (Epistolas 137,18)

Del mismo modo como Cristo vivió entre nosotros “sin apariencia ni belleza" (Is 53,12), la palabra de la Escritura aparece insignificante respecto de las espléndidas afirmaciones de los filósofos, pero muestra su forma divina a aquellos que son capaces de percibirla y, como se señaló, tienen la paciencia para escudriñarla. Como el Verbo habita en la naturaleza humana de Cristo sin quedarse encerrado en ella, así también la Palabra de Dios es más grande que las palabras humanas en que se expresa, sin resolverse completamente en ellas. Por eso, las palabras de la Escritura son insondables como el Logos divino es insondable, dicen mucho más de lo que se puede deducir cada vez de sus letras (Fiedrowicz, 2010, pp. 133-135). Agustín, tras haber despreciado las Escrituras durante su etapa maniquea, precisamente, por esta sencillez y aparente insignificancia, empieza poco a poco a comprender el hondo misterio que encierran y describe esta parte de su conversión así:

Reconociéndonos enfermos para hallar la verdad por la razón pura y comprendiendo que por esto nos es necesaria la autoridad de las sagradas letras, comencé a entender que de ningún modo habrías dado tan soberana autoridad a aquellas Escrituras en todo el mundo, si no quisieras que por ellas te creyésemos y buscásemos. $\mathrm{Y}$ en cuanto a los absurdos en que antes yo solía tropezar, habiendo oído explicar en un sentido aceptable muchos de sus lugares, lo atribuía ya a la profundidad de sus misterios, pareciéndome la autoridad de las Escrituras tanto más venerable y digna de la fe sacrosanta cuanto que es accesible a todos los que quieren leerlas, y reserva la dignidad de su secreto bajo un sentido más profundo, y, prestándose a todos con unas palabras clarísimas y un lenguaje humilde, da en qué entender aun a los que no son ligeros de corazón. (Confesiones, 6,5,8)

Ahora bien, es importante señalar que el aprecio que los Padres tienen por el sentido espiritual no les hace despreciar el sentido literal de la Escritura. Del mismo modo que en Cristo, hay una naturaleza humana y una naturaleza divina, así también en la Escritura hay un lado humano y un lado divino. Al lado humano e histórico corresponde el método histórico y filológico de la exégesis que los Padres practicaron según las posibilidades de la ciencia y los conocimientos a su alcance; a la dimensión divina 
corresponde la interpretación teológica o espiritual. Ninguna de las dos se puede absolutizar a costa de la otra; pero tampoco pueden estar juntas sin relacionarse. De manera análoga a la unión sin confusión y sin separación de las dos naturalezas en la persona de Cristo, también en la Escritura los dos sentidos deben ser distinguidos, no separados. Para los Padres el intérprete debe partir siempre del sentido literal.

Así pues, los Padres valoraban altamente la humanidad de la Escritura de modo análogo a cómo valoraban la fe en el Logos encarnado; a la vez que combatieron el docetismo cristológico (que reducía la humanidad de Cristo a mera apariencia), rechazaron una concepción docetista de la Escritura, que menospreciaba el sentido literal.

Además, en paralelo a la analogía con la Encarnación, hay también una analogía de la Palabra de Dios con la eucaristía. Comprendieron que los tres misterios de la Encarnación, la Escritura y la eucaristía están íntimamente ligados entre sí. En efecto, el cristiano que recibe la Palabra de la Escritura comulga espiritualmente con el Logos; esta Palabra no debe recibirse con menor respeto y atención que el cuerpo eucarístico de Cristo. Del mismo modo como la eucaristía no es simple recuerdo de un evento pasado, sino que reactualiza el sacrificio del Cuerpo del Señor ofrecido por nosotros y por nuestra salvación, así la Escritura no es ante todo historia de eventos pasados, sino forma de la Palabra de Dios emitida para nosotros incesantemente aún hoy. Veamos este principio en palabras de Orígenes:

Sabéis, vosotros que soléis estar presentes en los misterios divinos, cómo, cuando recibís el cuerpo del Señor, lo conserváis con toda cautela y veneración, para que no caiga la mínima parte de él, para que no se pierda nada del don consagrado. Os consideráis culpables, y con razón, si cae algo por negligencia. Pues si tenemos tanta cautela para conservar su cuerpo, y la tenemos con razón, ¿̨por qué creéis que despreciar la Palabra de Dios es menor sacrilegio que despreciar su cuerpo? (Homilías sobre el Éxodo XIII,3)

\section{Cristo: principio hermenéutico clave para la Escritura}

Aunque estemos tratando este tema como último punto, en realidad, es el fundamento de cuanto caracteriza la lectura espiritual de la Escritura: Cristo mismo es su riqueza porque se centra en él y desde él se interpreta.

Los Padres no tienen un único modo de leer la Escritura, sino que a veces buscan un doble sentido en ella (sentido literal/sentido espiritual), a veces uno triple (cuerpo/alma/espíritu de la Escritura) e, incluso, cuádruple (literal/moral/anagógico/alegórico). Hay variación entre los distintos autores, a veces hasta en distintas obras de un mismo autor. Orígenes, por ejemplo, al explicar su método de interpretación de las Escrituras, afirma que deben buscarse tres sentidos en ella y los hace corresponder con tres tipos de cristianos (los simples, los que van progresando, los perfectos) y con las tres partes de que está formado el ser humano (cuerpo, alma, espíritu); sin embargo, el Alejandrino en sus obras oscila entre proponer dos o tres sentidos, sin mantener unidad de método. Así explica su técnica exegética:

Cada uno... debería describir en su propia mente, en una manera triple, el entendimiento de las letras divinas, es decir, para que todos los individuos más simples puedan ser edificados, por así decirlo, por el cuerpo mismo de la Escritura; porque así llamamos el sentido común e histórico; mientras que, si algunos 
han comenzado a hacer progresos considerables y son capaces de ver algo más, pueden ser edificados por el alma misma de la Escritura. Aquellos, por otra parte, que son perfectos... pueden ser edificados por la ley espiritual misma, que es una sombra de las buenas cosas por venir, como si fuera por el Espíritu. Porque, así como se dice que el hombre está formado de cuerpo, alma, y espíritu, también la Sagrada Escritura, que nos ha sido concedida por la divina generosidad para la salvación del hombre. (Tratado de los principios, IV,2,4)

A pesar de la variedad de lecturas exegéticas entre los Padres, lo importante es que, en cualquiera de sus formas, se encuentra una estructura cristológica fundamental: ven en toda la Escritura el único misterio de Cristo prefigurado, actualizado, interiorizado, llevado a su cumplimiento.

Los Padres no se atribuyen a sí mismos la creación o el desarrollo de este método, sino que más bien afirman que se trata de un principio que han recibido de san Pablo, que decía en su carta a los Gálatas: "porque dice la Escritura que Abraham tuvo dos hijos, uno de la esclava y otro de la libre. Pero el de la esclava nació según la naturaleza, y el de la libre en virtud de la promesa. Hay en ello una alegoría, pues estas mujeres representan dos alianzas" (Ga 4, 22-24a); o en su primera carta a los Corintios: "todo esto les acontecía en figura, y fue escrito para aviso de los que hemos llegado a la plenitud de los tiempos" (1 Cor 10, 11). Así, por ejemplo, Orígenes, interpretando el hecho de que Isaac conozca a su futura esposa Rebeca junto a un pozo, sostiene:

¿O piensas tal vez que el que los patriarcas vengan a los pozos y sus bodas se decidan junto a las aguas son cosas que suceden siempre por casualidad? El que entiende así estos relatos es un hombre animal y no capta las cosas que son del Espíritu de Dios. Pero el que quiera, permanezca en este estado, manténgase animal; y yo, siguiendo al Apóstol Pablo, digo que estas cosas tienen sentido alegórico y digo también que las bodas de los santos son la unión del alma con el Verbo de Dios, pues el que se une al Señor es un solo espíritu. Y esta unión del alma con el Verbo es seguro que no puede realizarse de otra manera que por la instrucción de los libros divinos, que figurativamente reciben el nombre de pozos. Si uno viene a estos pozos y saca agua de ellos, es decir, si por medio de la meditación saca de ellos un sentido y una inteligencia más profundos, encontrará bodas dignas de Dios; pues su alma se une a Dios. ${ }^{8}$ (Homilías sobre el Génesis, 10)

La exégesis patrística, entonces, se caracterizaba por ver en toda la Escritura al Cristo total, el misterio completo de Cristo y de su Iglesia; he ahí el contenido central de toda la Escritura. "Bienaventurados los que pueden hoy, a través de esta apertura, explorar en todas sus dimensiones el Misterio de Cristo. Bienaventurados los que pueden fundar su mirada en las insondables riquezas de Cristo que los antiguos desearon ver y no vieron" (De Lubac, 1971, p. 481). En efecto, Cristo es el evento definitivo, el fin de la historia. Por ello, los cristianos interpretan las Escrituras judías desde el presente cristiano. La exégesis espiritual de la Escritura entiende el Antiguo Testamento a la luz y en el espíritu del Nuevo. La historia de la salvación interesa a los cristianos porque es su propia historia, cargada de un misterio que es el misterio de su vida. El cristiano no interroga a la Biblia como a una serie de documentos sobre el pasado, sino que "escruta las Escrituras" para descubrir en ellas el pensamiento y los designios de Dios sobre él.

8 Orígenes comenta el pasaje de Gn 24, 13 y ss. 


\section{Conclusión: algunas luces para la teología de hoy}

El interés que suscita para hoy esta breve introducción a la lectura espiritual de la Sagrada Escritura que los Padres de la Iglesia hicieron reside principalmente en la convicción de que esta interpretación tiene mucho que enseñarnos y puede enriquecer nuestro quehacer teológico. Obviamente, la nuestra es una época muy diferente de la suya, y lo adquirido hoy sobre los métodos científicos, históricos, filológicos y arqueológicos ha brindado importantes contribuciones para la exégesis y la teología de las que no podemos ni debemos prescindir. Sin embargo, acercándonos a los Padres y conociendo su método, podemos potenciar nuestra exégesis y enriquecer nuestra reflexión teológica y llegar, incluso, a superar algunas de las limitaciones que nos encontramos en la actualidad.

Ramelli (2015, p. 130) sugiere que muchas de las sensibilidades actuales en exégesis y hermenéutica de los textos bíblicos estaban ya presentes en los Padres; ellos buscaban, como buscamos hoy, una aproximación integral a la interpretación de la Escritura, una comprensión unitaria de la Biblia como supertexto y se esforzaban por enriquecer la comprensión del texto con los aportes de la filosofía y de las ciencias humanas. Los Padres proponían la unidad e integralidad de los saberes para un mejor acercamiento al texto sagrado y esta propuesta suya coincide con la inquietud actual por superar aquella excesiva especialización de los conocimientos que termina distanciando tanto las áreas del conocimiento como haciéndolas incapaces de dialogar entre sí y limitando la capacidad de estudiar juntos las verdades más hondas. Nuestro tiempo con sus desafíos reclama una aproximación integral al saber teológico y los Padres pueden ser maestros y guías para nosotros en este aspecto.

En el siglo XX, grandes teólogos han usado la aproximación patrística, y valiéndose de su conocimiento profundo del pensamiento cristiano antiguo, se han aproximado a los problemas teológicos de su tiempo y han ofrecido soluciones de síntesis a contradicciones que se arrastraban por años. Henri de Lubac, Hans Urs von Balthasar, Jean Daniélou e Yves Congar, por mencionar solo algunos, son ejemplos del modo como los Padres ayudan al pensar teológico a encontrar caminos de renovación (Beirne, 2012; Gresch, 2009; Oort, 2006; Wright, 2015) y tienen mucho que ofrecer para que también hoy podamos responder a los desafíos de un mundo en rápido proceso de descristianización.

Aprender de los Padres a percibir esa experiencia de la presencia del misterio en la Escritura, ese hondo sentido de la historia que no se pregunta solo, o, ante todo, si tal o cual evento sucedió históricamente de esa manera exacta y precisa, sino que se descubre cómo esa historia está cargada del Espíritu, de esa presencia del Dios que ha querido salir a encontrarnos en nuestra historia, puede ser una fuente de inspiración.

Leyendo espiritualmente la Escritura, miraremos con más profundidad y atención el significado eterno de grandes episodios bíblicos, siempre a la luz del misterio cristiano, aprendiendo a reconocer mejor la eterna juventud del texto antiguo.

Leyendo espiritualmente la Escritura, haremos más theologia, leyendo nuestra propia historia actual con sus vicisitudes, sus contradicciones, su devenir, descubriremos en ella la misma eterna juventud de la Escritura. Para el cristiano, toda historia es lugar de salvación. La historia bíblica, pero también nuestra historia, nuestro tiempo contemporáneo lleno de contradicciones, dificultades, sorpresas. Los teólogos 
podemos dar este servicio: fundada en una ciencia experimentada, una exégesis sanamente espiritual se podrá difundir nuevamente para enriquecimiento de la Iglesia (De Lubac, 1971, p. 470).

\section{Referencias}

Agustín de Hipona. (2019 ed.). Confesiones (A. C. Vega Rodríguez, J. Rodríguez Díaz, trads.). Madrid: Biblioteca de Autores Cristianos.

Agustín de Hipona. (1957 ed.). La doctrina cristiana (B. Martín Pérez, trad.). Madrid: Biblioteca de Autores Cristianos.

Agustín de Hipona. (1987 ed.). Epistolas (L. Cilleruelo, trad.). Madrid: Biblioteca de Autores Cristianos.

Agustín de Hipona. (1955 ed.). Tratados sobre el Evangelio de san Juan (T. Prieto, ed.; V. Rabanal, trad.). Madrid: Biblioteca de Autores Cristianos.

Ambrosio de Milán. (1966 ed.). Obras de San Ambrosio: Tratado sobre el Evangelio de San Lucas (M. Garrido Bonaño, ed.). Madrid: Biblioteca de Autores Cristianos.

Beirne, M. M. (2012). Spiritual Enrichment through Exegesis: St Gregory of Nyssa and the Scriptures. Phronema, 27(2), 83-98. Recuperado de http://www.sagotc.edu.au/sites/default/files/files/beirne/PHRONEMA_20122_ Beirne.pdf

Concilio Vaticano II. Dei Verbum. Nov 18 de 1965. http://www.vatican.va/archive/hist_councils/ii_vatican_council/ documents/vat-ii_const_19651118_dei-verbum_sp.html

Dal Covolo, E. (2010). Il Vangelo e i Padri: Per un'esegesi teologica. Roma: Rogate.

De Lubac, H. (1971). Storia e spirito: La comprensione della Scrittura secondo Origene. Roma: Edizioni Paoline.

De Lubac, H. (1988). Catolicismo: aspectos sociales del dogma. Madrid: Encuentro.

Dell'Osso, C. (2016). Introduzione alla teologia dei Padri: Temi di teologia patristica per principianti. Verona: Fede e Cultura.

Fiedrowicz, M. (2010). Teologia dei Padri della Chiesa: Fondamenti dell'antica riflessione cristiana sulla fede. Brescia: Queriniana.

Gregorio de Nisa. (2012 ed.). Homilias sobre el Eclesiastés (O. Peveraro y R. Cornavaca, eds.). Madrid: Ciudad Nueva.

Gregorio de Nisa, Orígenes. (2016 ed.). Sul Cantico dei cantici (V. Limone y C. Moreschini, eds.). Milán: Bompiani.

Jerónimo. (1995 ed.). Epistolario (J. B. Valero, ed.). Madrid: Biblioteca de Autores Cristianos.

Juan Crisóstomo. (1970 ed.). Sur l’incompréhensibilité di Dieu (A. M. Malingrey y J. Danielou eds.; R. Flacelière, trad.). París: Éditions Du Cerf.

Kannengiesser, C. (2004). Handbook of patristic exegesis: The Bible in ancient Christianity. Leiden: Brill.

Padovese, L. (1996). Introducción a la teología patrística. Estella: Verbo Divino.

Orígenes. (1986 ed.). Comentario al Cantar de los Cantares (M. Simonetti, ed.; A. Velasco Delgado, trad.). Madrid: Ciudad Nueva. 
Orígenes. (1999 ed.). Homilías sobre el Génesis (J. R. Díaz Sánchez-Cid, ed.). Madrid: Ciudad Nueva.

Orígenes. (1999 ed.). Omelie sul Levitico (M. I. Danieli, ed.). Roma: Città Nuova.

Orígenes. (2015 ed.). Sobre los principios (M. Simonetti, ed.; S. Fernández, trad.). Madrid: Ciudad Nueva.

Orígenes. (1992 ed.). Homilías sobre el Éxodo (M. I. Danieli, ed.; Á. Castańo Félix, trad.). Madrid: Ciudad Nueva.

Ramelli, I. (2015). Patristic Exegesis: Relevance to Contemporary Biblical Hermeneutics. Religion \& Theology, 22(12), 100-132. https://doi.org/10.1163/15743012-02201008

Simonetti, M. (1985). Lettera elo allegoria. Roma: Instituto Patrístico Augustinianum.

Wood, S. K. (1998). Spiritual Exegesis and the Church in the Theology of Henri de Lubac. Míchigan: Eerdmans.

Wright, W. M. (2015). Patristic exegetical theory and practice in de Lubac and Congar. New Blackfriars, 96(1061), 61-73. https://doi.org/10.1111/nbfr.12082 